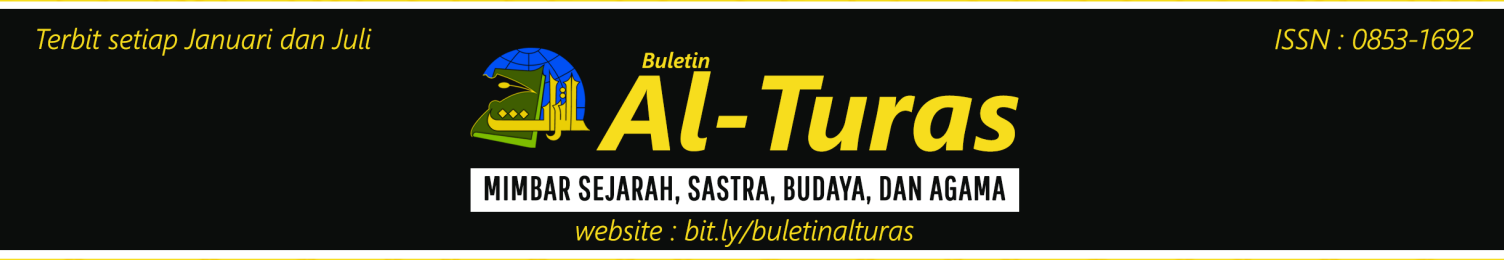

\title{
Syariah Law and The Rights of Non-Muslims: The Importance of Reinterpreting traditional Syariah And Disseminating Progressive Syariah
}

\author{
Sukron Kamil ${ }^{1}$
}

\section{Abstract}

During the era of Reformasi the face of Indonesian politics was marked by, among other things, the kindling in a number of regions of the formalizing of Islamic law through regional bylaws, and in other areas through public policy. Efforts to achieve this started at the third level, that is at the level of regulating aspects of religious services and worship, going beyond Islamic family and economic law, and this was also the case with formalizing shariah law at national level.Despite the positive impacts of thissuch as improved security, seen from the perspective of the rights of non-Muslims the implementation of regional Islamic regulations or public policy is a threat, in part because of its positioning as something that may trigger the violation of non-Muslim rights. Shariah bylaws are a close reflection of traditional Islamic law. Because of this, the shariah law already embodied in regional legislation must be reinterpreted to make it something of benefit to people, providing a sound footing for accomodating such contemporary demands as basic human rights. In any case, the shariah that becomes formalised in bylaws should be progressive and modern, and this is the shariah law that needs to be publicised and supported.

Keywords: shariah bylaws,dzimmî, mainstream, hudîud, khalwat, jizyah, ahl al-kitâb, takwil,and istishlâh.

\section{Abstak}

Selama era reformasi, wajah perpolitikan Indonesia ditandai dengan adanya, antara lain, menjamurnya jumlah daerah-daerah yang memberlakukan hukum Islam melalui peraturan daerah, melalui kebijakan publik. Usaha untuk memeroleh hal ini dilakukan dengan tiga tingkatan, yaitu pada tingkat pemberlakuan aspek-aspek keagamaan, pelayanan dan peribadatan, kemudian berlanjut pada masalah hukum ekonomi dan keluarga islami, dan hal ini juga menjadi masalah pemberlakuan hukum syariah pada tingkat nasional.Meskipun dampak positif semacam ini dapat meningkatkan keamanan, ditinjau dari perspektif hak-hak non-muslim terhadap pemberlakuan peraturan daerah atau kebijakan publik menjadi sebuah ancaman, dikarenakan posisinya sebagai sesuatu yang bisa memicu pelanggaran hak-hak non-muslim.Perda syariah merupakan refleksi hukum islam klasik. Hal ini dikarenakan hukum islam mencakup peraturan daerah yang harus ditafsirkan untuk memberikan manfaat bagi masyarakat, dengan menampung aspirasi suara bawah.

Keywords: shariah bylaws,dzimmî, mainstream, hudîud, khalwat, jizyah, ahl al-kitâb, takwil,and istishlâh.

\footnotetext{
${ }^{1}$ Faculty Adab and Humanities UIN Syarif Hidayatullah Jakarta
} 


\section{A. Introduction}

During the era of Reformasi the face of Indonesian politics was marked, among other things, by the kindling in a number of regions of the implementation of Islamic law. This occurred in least 22 cities or districts, however other sources quote a number of $50 .{ }^{2}$ Examples of this have occurred in the Nangroe Aceh Darussalam Province; in Bulukumba District, South Sulawesi; in Bima, West Nusa Tenggara; in Indraymayu, Cianjur and Tasikmalaya, West Java; and in the city of Tangerang, in Banten, This phenomena can be seen in the appearance of regional bylaws (Perda) at provincial, district and city levels, in Strategic Plans, Directives, Instructions and Circulars from District Heads and Mayors, and other rulings about implementing Islamic or Islamic-nuanced law in a variety of forms. At the lowest level the shariah rulings deal only with prostitution and drinking alcoholic spirits (as mainstream regulations) that are already controlled by the Criminal Code (KUHP), as is the case in Tangerang; the mid level includes matters such as Friday prayers, a requirement to be able to read the Koran, Muslim dress and Islamic alms-giving; and the highest level is implementation of Islamic criminal law. This last level has only occurred in Aceh. One example of this is whipping for gamblers and for illicit liaisons between adult males and femalesin secluded places. ${ }^{3}$

Efforts to introduce shariah bylaws are understandable, given that since the first years of Indonesia's inception in the 1940s there have been efforts to im-

\footnotetext{
${ }^{2}$ Tempomagazine, 14 May 2006, p. 29

${ }^{3}$ Sukron Kamil et al., Syari'ah Islam and HAM, Dampak Perda Syariah terhadap Kebebasan Sipil, Hak-Hak Perempuan, and Non Muslim, Jakarta, CSRC UIN Jakarta and KAS, 2007, $115-125$
}

plement shariah law at the national central government level. These efforts ultimately failed with in 2002 the defeat of a movement to amend the Constitution by reinstating a clause in the Jakarta Charter which stated; “... with the requirement for Muslims to follow Islamic law." The movement to reinstate the Jakarta Charter was backed by (among others) Islamic political parties like the Partai Bulan Bintang (PBB, Crescent Moon and Star Party) and the Partai Persatuan Pembangunan (PPP, United Development Party). With the benefit of Law 22/1999 on regional autonomy, efforts to implement shariah took a new form, that of regional implementation. This is because the law devolved 11 central government responsibilities to regional governments. ${ }^{4}$ Although this law specifies five areas (including religious matters) in which authority remains with the central government ${ }^{5}$, it also provided that regional bylaws no longer needed to be ratified by the central government, as long as they were not inconsistent with the public interest and they did not conflict with higher legislation. Subsequently this law was revised by law 32 of 2004, which provided that a provincial law required ratification by the central government, and district laws required provincial ratification. The exception to this was Nanggroe Aceh Darussalam (NAD), which was given special status by law 11 of 2006 concerning the governance of Aceh. However until now, because of technical and political considerations, shariah bylaws have been allowed to remain in force completely untouched by

\footnotetext{
${ }^{4}$ These responsibilities arefor land, agriculture, education and culture, the workforce, health, environment, public works, transport, trade and industry, capital investment and cooperatives.

${ }^{5}$ The areas offoreign policy, defense and security, justice, monetary and fiscal policy, and religion.
} 
central government.

This paper aims to examine the formalisation of shariah law through provincial regulations (Perda), or likewise through Notices of Directive (SK) by District Heads (Bupati) as has happened at Cianjur, and the implications of this implementation for non-Muslims. Further, it will analyse the contextual perspective of the laws' construction, and also the perspective of traditional Islamic law and its reinterpretation. There is pressing need for this discussion, as in the view of the Indonesian sociologist Moeslim Abdurrahman, when Islamic law is enacted the first to feel its effect are women, non-Muslims, and the poor. ${ }^{6}$ This paper aims to demonstrate the truth or otherwise of this statement.

\section{B. Discussion}

\section{Anoverview of regional shariah laws and Islamic influenced district regula- tions, and the public response}

Based on the criteria of Daniel $E$ Price $^{7}$, the Islamic law implemented in different regions in the form of bylaws or Islamic influenced regulations has just reached the third level, that is the level of regulating religious rituals (forms of worship). The regulation of ritual takes a variety of forms:from regulations for closing main roads during Friday devotions in Bima (West Nusa Tenggara), or at ordinary prayer times in Biruen (Nangroe Asceh Darussalam - NAD); the prerequisite that prospective marriage partners and government officials in Bulukumba (South Sulawesi) be able to read and write texts from the Koran, to requirements that cafes and shops close

${ }^{6}$ Interview with Ulil Absar Abdalla and Moeslim Abdurrahman, <http://www.mail-archive.com/ eskol@mitra.net.id/msg00107>,last accessed 21 April 2006.

${ }^{7}$ Arskal Salim and Azyumardi Azra, Syari' $a$ and Politics in Modern Indonesia, Pasir Panjang: ISEAS, 2003, p.11 during prayer times, especially evening payers and Friday devotions, as in Biruen, NAD. Generally, implementation of Islamic law in the form of enacting regional bylaws is only at the first level (family law) and level two (economic law), namely Muslim clothing, management of alms giving, charitable donations and contributions (although this could be said to be level one), regulations for compulsory religious schooling and for lessons on shariah economics, as at Tasikmalaya. ${ }^{8}$

Shariah or shariah influenced bylaws or regulations that prohibit or regulate alcoholic spirits, prostitution and gambling are mainstream regulations, howeverin needs to be stated that the content load of these three issues in no way reflects Islamic law. The form of punishment or sanction prescribed by these bylaws, for example, is not in accord with the form of punishment as regulated by Islamic law, except in Biruen and other districts of Aceh. From this viewpoint, labeling mainstream bylaws covering these three issues as Islamic laws seems to represent a simplification, or even an inaccuracy. This is the observation of Professor Jan Michiel Otto, Director of the van Vollernance Institute for Law, Governance, and Development at the University of Leiden in the Netherlands. According to him, as long as these bylaws that are said to be Islamic law contain prohibitions against gambling, prostitution and alcoholic spirits, they are in fact no different from the Criminal Code (KUHP) which has regulated these three activities since the government of the New Order. ${ }^{9}$ This is because bylaws covering these three things can only be described as regulations to strengthen the Criminal Code, and can also be said to turn 'norms for living' into 'laws for living'. The argument is that the local values of the people already hold that gambling, drinking alcoholic spirits and prostitution are morally offensive to local customs.

\footnotetext{
${ }^{8}$ Sukron Kamil et al., Syari'ah Islam and HAM, pp. 125-129

${ }^{9}$ Kompas newspaper, 16 August 2007, p. 45
} 
Despite this, because the essence of forbidding these three things derives from religion, especially in the context of Indonesian Islamic law, and moreover because those local customs spring from cultures influenced by religion, particularly Islam, mainstream bylaws can surely also be said to have sharih law overtones, and be influenced by shariah law. As well as this, in the context of Aceh the form of punishment for the three offences above closely reflects Islamic law. Moreover, as will be explained, it would not be a mistake to consider bylaws for issues other than the three mentioned, such as veil wearing, Friday devotions and illicit liaisons, as Islamic bylaws.

However in Bireun and other districts of Aceh, the Islamic law implemented has already reached the fourth level, that of Islamic criminal law. The only thing Aceh has not undertaken is an Islamic nation. Nevertheless, some aspects of the Islamic criminal law adopted in Aceh have certain limitations, mainly in being based on ta'zir, or punishment determined by an Islamic magistrate, rather than hudud, or punishment according to the literal words of the Koran or Hadiths. Thus:

- Aceh's bylaw 13/2003 forbids gambling, and gamblers are liable to a minum of five strokes of the cane and a maximum of twelve. Institutional offenders are liable to a fine of between 12 and 35 million rupiah.

- Aceh's bylaw 14/2003 makes khalwat an offence, being illicit liaison in secluded places between adult males and females, with actions tending to lead to immorality. Under this bylaw offenders will receive no less than three and no more than nine strokes of the cane, with or without a minimum fine of 2.5 million and a maximum of 10 million rupiah.

- Aceh bylaw 12/2003 makes drinking alcoholic spirits an offence, with offenders liable to a minimum of four strokes of the cane, according to traditional shariah law.

With regard to legal promulgation, application of these parts of shariah criminal law is made possible under the protection of sections 3 and 4 of National Law 44 of 1999 concerning Implementing Aceh's Special Status, National Law 18 of 2001 concerning Special Autonomy for Aceh, and National Law 11 of 2006 concerning the Governance of Aceh. Apart from Aceh, Desa Padang, (in Gantarang, Bulukumba) has also implemented level four shariah law, and has village regulations in place covering adultery, unproven accusations of adultery and alcohol and gambling, in accordance with traditional Islamic law. Thus the penalty for adultery is 100 strokes of the cane, wrongful accusations of adultery, 80 strokes, drinking alcoholic spirits, 40 strokes, while the penalty for gambling is at the discretion of the magistrates.

Other places apart from NAD and Desa Padang have formalised and implemented Islamic law. They have done this through local bylaws or through policy that carries political weight, such as a circular instruction from the district head. However the shariah law they have implemented is not very far removed from the level of shariah law implemented and applied across the nation. This is because the shariah law implemented nationally is at level two, or perhaps level three, governing the practices of religious observance.

In matters of family law, for example, Indonesia has:

- National Law 1 of 1974 which legally validates religious (as opposed to civil) marriages.

- National Law 7 of 1989 concerning religious courts which can handle some civil matters for Muslims, including marriage, inheritance, wills, gifts, 
endowments and charitable donations. This law is reinforced by National Law 3 of 2006 which gives additional authority to religious courts in matters of Islamic alms-giving and shariah economic matters.

- Presidential Instruction 1 of 1991 concerning compilation of Islamic marriage, inheritance and endowment laws.

In Islamic economic law, Indonesia has:

- National Law 7 of 1992, which authorises banks which operate on a shariah system of profit and loss sharing, and

- National Law 10 of 1998 which guides conventional banks towards opening shariah branches, or even converting themselves into wholly shariah banks.

In the regulation of religious matters, there is:

- National Law 28 of 1977 which deals with making endowments, and was revised by National Law 41 of 2004 concerning endowments that carried implications for questions of Muslim community economics.

- National Law 38 of 1999 which also concerns issues of alms-giving and endowments that have economic implications for the Muslim population.

- National Law 17 of 1999 which concerns haj pilgrimages to Mecca. ${ }^{10}$

\footnotetext{
${ }^{10}$ Gatra magazine, edition 6 May2006.
}

The writer and a team from the Center for the Study of Religion and Culture (CSRC, UIN Jakarta) carried out survey in six regions ${ }^{11}$ into the response of the public to the shariah bylaws discussed above. The survey revealed that the majority (94.7\%) of Muslim repondents agreed with formalizing shariah law in provincial bylaws. The majority (92.8\%) of Muslim respondents also believed that these bylaws were needed by the people. Additionally, shariah bylaws were supported by nearly half $(46 \%)$ of non-Muslim respondents. The main reason that the Muslim community agrees with formalizing Islamic law as Provincial bylaws is that for them these things are religious commands. In this context, the bylaws are seen as enacting the doctrine that makes it imperative for religious teachings to be followed in toto, without exception. ${ }^{12}$

Firstly, the data show that the religious perspective of Indonesia's Muslims tends towards 'stateism' rather than a civil society perspective that downplays the necessity of state dominance and affirms the autonomy of individuals from the state. From the civil society perspective, as seen in the United States, implementing religious teachings need not involve the state, but is the proper domain of family and community. Despite this, several other secular nations, such as England, recognise that the laws of the Anglican Church have the same strength in court as the common law ${ }^{13}$, although this is optional in nature. A state-oriented perspective such as this is understandable. Since the time of classical Islam, particularly since the Umayyah Dynasy (661 - 750 AD), in historical practice the relationship between state and religion was organic and indivisible. The concept of separating the

${ }^{11}$ These six districts are Bireun, Nangroe Aceh Darussalam Province; Bulukumba, South Sulawesi; Bima, West Nusa Tenggara; Indramayu, Cianjur, and Tasikmalaya, West Java; and Tangerang city, Banten.

${ }^{12}$ Sukron Kamil et al., Syari'ah Islam and HAM, p.131-132

${ }^{13}$ Abdullahi Ahmed An-Na'im, Islam and Negara Sekular, Menegosiasikan Masa Depan Syariah, Bandung: Mizan, 2007, p. 218 
state and religion is still new, and is rejected by the grass roots Muslim population. Consequently, although the construct of the Indonesian State is secular, or at least semisecular (as can be seen by Pancasila and the Department of Religion), there is an ongoing tug of war, with political Islam proponents pulling in the direction of theocracy while the formerly dominant but now weakening nationalists pull towards secular rule. ${ }^{14}$

Secondly, the public's religious perspective favouring shariah bylaws differs from view taken by the biggest Islamic organizations in Indonesia, Nahdhatul Ulama (NU) and Muhammadiyah, which support Indonesia's form as a nation-state. Although they reject the formalisation of shariah, at least at the level of criminal law, in practice many of their members are much involved in movements for implementing Islamic law in various regions. ${ }^{15}$ Thirdly, it appears that when shariah is mentioned, Muslims members of the public whose religion may not be strong are afraid, or have a mindset which makes it hard for them to refuse it, even in relatively high level bylaws.

Another principal reason, according to the majority of the respondents in the writer's joint research (with CSRC), is that in their considered opinion shariah bylaws may be a way out of the various problems afflicting the country. This viewpoint tallies with the claims of Islamic groups such as MMI (Majlis Mujahidin Indonesia) and HTI (Hizbut Tahrir Indonesia), and with proponents of shariah bylaws such as senior religious leaders Jalaluddin Amien and Sanusi Baco (former Chairman for Regional Affairs, Muhammadiyah and NU South

\footnotetext{
${ }^{14}$ For this, see also Bahtiar Effendi, Islam and Negara; Tranformasi Pemikiran and Praktek Politik Islam di Indonesia, Jakarta: Paramadina, 1998 and Abdul Azis Thaba, Islam and Negara dalam Politik Orba, Jakarta: Gema Insani Press, 1996

${ }^{15}$ Kompas, 19-03-2002 and Taufik Adnan Amal and Samsu Rizal Panggabean, Politik Syari'at Islam, Dari Indonesia Hingga Nigeria, Jakarta: Pustaka Alvabet, 2004, p. 99
}

Sulawesi).${ }^{16}$ As well as this, in the opinion of a small sector of the population, shariah bylaws are a living force in the community, and have become part of the region's special unique character.

From the above explanation, theological factors are seen to play a powerful part in building public support for shariah bylaws. However a further strong factor is the stagnating or failed reform of the economic, law, order and good governance sectors, which leads grass roots Muslims to see shariah bylaws as a solution to the different crises affecting the nation. In a qualitative sense, this appears as the strongest factor, as suggested by Syafi'i Ma'arif. According to him, the shariah bylaw phenomena in regions across Indonesia arose following the introduction of regional autonomy, because Islam's grand humanitarian values, such as social and economic justice, were not being realised. ${ }^{17}$ Azyumardi Azra holds the same opinion. ${ }^{18}$ $\mathrm{He}$ believes that the enacting of shariah bylaws in a number of regions of Indonesia is very much a reflection the material woes felt by the Muslim population. He also considers the efforts to apply Islamic sharia law to be a self-defence mechanism, in the sense that this is the only way not only to strengthen the Muslim peoples, but at the same time to resolve a wide variety of social ills. They are convinced that adopting shariah law is panacea, an all purpose elixsir, that can once and for all cure the country's multi-dimensional ills and overcome every crisis, particularly those affecting politics and the economy. ${ }^{19}$ This grass roots Muslim

${ }^{16}$ Haedar Nashir, Gerakan Islam Syari'at, Reproduksi Salafiah Ideologis di Indonesia, Jakarta: PSAP, 2007, p. 390, 316

${ }^{17}$ Kompas newspaper, 3-1-2002

${ }^{18}$ Azyumardi Azra "Syari'at Islam dalam Bingkai Nation State", pp. 30-32

${ }^{19}$ Another world intellectual who holds the same opinion is Louay M. Shafi. According to him, the push towards implementing shariah law emerged after part of the Muslim elite realized that the strength of its ideology of development had produced progress in the political and social life of the people. What it had produced was the 
expectation can be labeled as escapist, placing its trust in a shariah-inspired order.

Although the majority of Muslim respondents agreed with formalizing shariah bylaws, $35.5 \%$ of non-Muslims disagreed (46\% of them agreed), because they believed that shariah bylaws would "disturb the harmony of religious followers" and trigger acts of violence. Among public civil society organizations (including religious and secular interest groups), the issue of shariah bylaws is controversial. Among the Muslim groups, $40.8 \%$ believed that nonreligious mass organizations rejected the enactment of shariah bylaws, and $11.3 \%$ of them said that some political parties joined in this rejection. Some respondents (around $7 \%$ ) even stated that some religious mass organizations rejected shariah bylaws. ${ }^{20}$

In Tangerang city, for example, those opposed to the prostitution bylaw, often said to be shariah influenced, includeJMM(Jaringan Masyarakat Miskin, the Poor People's Network) and SPN (Serikat Pekerja Nasional, the National Workers' Union). Those who supported the bylaw included:

- BKMT (Badan Kontak Majlis Ta'lim - Religious Studygroups Contact Body),

- FPI (Front Pembela Islam Islam Defenders' Front),

- HTI (Hizbut Tahrir Indonesia, a Muslim religious group),

appropriation of power by the dominant class in its own interests and for its own luxurious lifestyle. In post-colonial Muslim countries the ruling elite worked towards and succeeded in enriching themselves and their cronies, while surrounded by public poverty. Furthermore, the authoritarian and repressive system of government run by the Muslim elite also influenced the beginnings of a push for implementing shariah. See Taufik Adnan Amal and Samsu Rizal Panggabean, Politik Syari'at Islam, p. 176.

${ }^{20}$ Sukron Kamil et al., Syari'ah Islam and HAM,p. 131-137
- The major religious organizations Muhammadiyah and NU (Nadhatul Ulama),

- PKS (Partai Keadilan Sejahtera - Prosperous Justice Party),

- PDS (Partai Damai Sejahtera - Peace and Prosperity Party),

- PGRI (Persatuan Guru Republik Indonesia - Teachers' Association of the Indonesian Republic),

together with members of the public and preachers who staged a long march in support of the prostitution bylaw. ${ }^{21}$

\section{The impact of shariah bylaws on the rights of non-Muslims}

Generally speaking, shariah bylaws as formalizing shariah law have both positive and negative effects. According to the writer's survey (in conjunction with CSRC colleagues), the majority of respondents in areas with shariah bylaws saw one positive effect as the creation of an environment in which people were more religiously devout, although $6.5 \%$ of respondents saw this only as the result of compulsion. These respondents saw the resultant religious devotion as artificial rather than morally honest, even though sincerity is a principal element of religious belief. This small group aside, $40 \%$ of respondents stated that a further positive effect, ${ }^{21}$ Sukron Kamil et al., "Pengaruh Regulasi Bernuansa Syari'ah terhadap Kehidupan Masyarakat Kota Tangerang: Studi terhadap Perda Pelacuran, regulasi tentang perkawinan, and agama", Laporan Hasil Riset, ["The effect of shariah-nuanced regulations on public life in the city of Tangerang: A study of provincial regulations for prostitution, marriage and religion", Report of Research Results], Jakarta CSRC UIN Jakarta and Respect Program, 2008. 
security and public order, was more assured. For example in Biruen, after the legal threat of caning was carried out on alcohol drinkers and gamblers in front of Biruen's Grand Mosque (Masjid Raya) in April - May 2005, instances of young children being drunk and of gambling in village laneways disappeared. ${ }^{22}$ However the data show that at that time the role of the state (the police force) in generating feelings of public security was extremely weak. As another example, according to Bulukumba's District $\mathrm{Head}^{23}$, after that region implemented a bylaw for charitable contributions (zakat, infak and sedekah), donations collected totalled five or six times more than tax, although according to the chairman of Bazis (the body responsible for collecting the donations), this number was only an estimate and not the actual amount. ${ }^{24}$

Despite this, in the case of Biruen, one of the negative impacts of codifying shariah law was a decline in the region's government income from some sectors of the economy. After the legal threat of caning was carried out for illicit meetings between unmarried males and females (khalwat) and for drinking alcohol, the tourism sector in Biruen experienced a dramatic fall. ${ }^{25}$ Formalizing shariah law as bylaws has also had negative impacts on civil rights, the rights of women, and the rights of non-Muslims. The bylaws adopted threaten, and in some cases even violate these three rights.

In the Cianjur region, where the District Head circulated a letter about

\footnotetext{
${ }^{22}$ Interview with Pastor Rasimin, a pastor of a church in Bireun, 9-08-2006.

${ }^{23}$ Tempo magazine, 14 May 2006, p. 26.

${ }^{24}$ Interview with Haji Tjamirudin, August 2006.

${ }^{25}$ Interview with Murdani Yusuf, Chairman of Commission A, DPRD [parliament], Bireun, 1008-2006.
}

wearing the jilbab, there was a report of a non-Muslim woman being forced to wear Muslim dress to the office every Friday. Others who have been required to wear a jilbab include a post office employee, a teacher at a national school and a high school (SMU) student. The parents of students who do not want comply must submit a letter of request and a statement that the student is non-Muslim. However this concession does not apply to the teachers, because it is they who must enforce the jilbab rule very Friday. The same applies in Padang, West Sumatera. When National High School (SMU) 1 in Padang required female students to be veiled, the regulation was also applied to non-Muslim students. For example Fransiska Silalahi, a Christian, had to be veiled for her three years of schooling at this high school. ${ }^{26}$ Moreover, in Cianjur a number of non-Muslim restaurants have been damaged by Islamic 'hard-liners'. A number of non-Muslim families have also been forced to move from where they were living, where the majority of the community was Muslim. ${ }^{27}$

This also occurred in Aceh after Provincial Regulation 5 of 2000 (section 15 subsections 4 and 5) came into effect, regulating dress codes and applying equally to non-Muslims and tourists. On flights to Aceh it is a common sight to see previously unveiled women suddenly putting on a veil, and around Banda Aceh Caucasian women in ones and

\footnotetext{
26“'Fransiska Silalahi: 'Kami Kesel BangetPake Jilbab" "["We're sick and tired of wearing a jilbab"], inJurnal Perempuan 60, Edisi September 2008, Jakarta; Yayasan Jurnal Perempuan, 2008, pp. 116-119

${ }^{27}$ Lihat Pramono Ubaid Tantowi,"Muslim and The Limits of Tolerance, Non-Muslim Minorities under Sharia in Indonesia,"Research report, Research Fellowship for Young Moslem Scholars, Bangkok: AMAN, 2003-2004.
} 
twos can often be seen wearing veils just for the sake of wearing them, although according to the Head of the Shariah Service wearing veils (jilbab) does not affect non-Muslims. ${ }^{28}$ In practice, the process of 'jilbabisation' for women of Chinese descent has taken place for female BCA (Bank Central Asia) employees. $^{29}$

More than this, once again based on surveys by CSRC (above), shariah bylaws appear to have an indirect trigger effect. This occurs because most Muslims in areas which enact shariah bylaws are intolerant of followers of local religions such as Sunda Wiwitan, of non-Muslim schools in Muslim areas, of non-Muslim civil service officials, and of non-Muslims in public office. In fact about half of them agreed that the public service should give priority only to Muslims, and a third of them do not agree with non-Muslims trading in Muslim areas and feel uncomfortable living in the same area as non-Muslims. Moreover, almost all Muslims (92.3\%) do not accept atheists.

In practice, most non-Muslims in areas where shariah bylaws apply have experienced damage to their places of worship; $40 \%$ of non-Muslims have been evicted from Muslim communities; according to about $40 \%$ of Muslims themselves the community does not have freedom of religion and Christians should be forbidden to conduct services or the Mass in their houses; $30 \%$ of non-Muslims have had difficulty obtaining building permits for places of wor-

\footnotetext{
${ }^{28}$ Interview with Ali Yasa' Abubakar, Head of the Islamic Shariah Service, NAD, 16-08-2006.

${ }^{29}$ Ibidand Lily Zakiyah Munir, "Simbolisasi, Politisasi and Kontrol terhadap Perempuan di Aceh"in Burhanudin (Ed.), Syariat Islam Pandangan Muslim Liberal, Jakarta: JIL, 2003, p. 133.
}

ship, in becoming public servants, or have experienced inequalities in obtaining subsidies; and $10 \%$ of non-Muslims have not been allowed to open restaurants/food stalls during the Ramadan fasting month, have been forced to wear a jilbab, or have been blocked from become leaders. ${ }^{30}$

In relation to Muslim tolerance of non-Muslims, other research carried out by CSRC in Tangerang city, which is included in the areas which apply shariah regulations, shows that tolerance depends on spheres of activity and issues. The closer the connection with Islamic convictions and rituals, the more Muslims tend to be intolerant. Examples of this concern the question of building places of worship, of non-Muslim schools in Muslim areas, and of religious services in predominantly Muslim housing areas. However the more the issue tends towards worldly social and economic matters, the more tolerant they become. In this context shariah bylaws seem not to have a direct impact, but to act as an indirect trigger. Comparing tolerance levels, generally speaking non-Muslims have higher tolerance levels that Muslims. They are extremely tolerant both in matters related or close to faith and ritual, and also in social and economic matters. ${ }^{31}$ Their position as non-Muslims and their education levels, which are higher than those of Muslims, apparently influence their different attitude of tolerance with Muslims.

In the matter of Ahmadiyah, according to a survey by the writer and colleagues from CSRC in six shariah bylaw regions in 2006 (above), more

\footnotetext{
${ }^{30}$ Sukron Kamil et al, Syari'ah Islam and HAM, p.184-207

${ }^{31}$ Sukron Kamil,et al, "Pengaruh Peraturan Perundangan Bernuansa Syariah terhadap Kehidupan Masyarakat Kota Tangerang, 2008.
} 
than half the population (68\%) affirmed that this sect was forbidden in their districts because its religious teachings are considered to be outside the mainstream or deviant. Another survey confined to Tangerang city (which applies shariah-influenced bylaws), also carried out by the writer and CSRC colleagues in 2008, showed that the general Muslim community demanded the dissolution of Jema'at Ahmadiyah. It was considered to be a sect which defiles Islam as a religion, and threatened the pure Islamic faith. Only $6 \%$ of respondents rejected the dissolution of Ahmadiyah. According to a small part of Tangerang's Muslim community, apart from the fact that dissolving Ahmadiyah would be contrary to freedom of religion, and not all Ahmadiyah followers believe in Mirza Ghulam Ahmad as a prophet, Ahmadiyah should be determined as not belonging to Islam. ${ }^{32}$

Of course, shariah bylaws or theological reasons are not the only factors which result in the Muslim community's attitude of rejecting Ahmadiyah. Another powerful factor in Presidential Decree 1 of 1965 concerning defiling religion, and paragraph 156a of the Criminal Code (KUHP). These two regulations were later strengthened by Joint Determination (SKB) 3/2008 by the Ministry of Religion, The Ministry of the Interior and the Public Prosecutor, which ordered that Jema'at Ahmadiyah cease its religious propagation, interpretation and activities which diverge from the core teachings of Islam.

As a result, in Tangerang the Jema'at Ahmadiyyah was required by the Sub-district Head to stop its internal religious activities, such as prayers at the Annur mosque in Babakan, Tangerang.

${ }^{32}$ Ibid.
This action was taken under public pressure, despite an earlier meeting between Ahmadiyah, police and the local Indonesian Council of Ulama (MUI). The Ahmadiyah management, whose members number some 1,000 people, was forced to remove all signage and insignia bearing the name of Ahmadiyah. ${ }^{33}$ In other places, most of which are not shariah bylaw areas, Ahmadiyah have been subjected to violence, for example in Parung Bogor, Sukabumi, Kuningan, Lombok and Bulukumba (the last two of these have shariah bylaws).$^{34}$ In Lombok, West Nusa Tenggara Province, about 137 Ahmadiyah people were forced to become refugees from their own villages. ${ }^{35}$

Furthermore, the emergence of shariah bylaws also threatens religious freedom, because in such areas $44 \%$ of the community agrees with the death penalty for apostates (people who change religion), while around 36\% disagree. This remains a threat only, as while it is possible for shariah law to be applied to the issue, the likelihood of this happening is small. However at the very least, people who change religion are treated socially as enemies and ostracized by their families.

Shariah bylaws also threaten or provoke violation of another non-Muslim right, the right to inter-faith marriage, especially with a Muslim. In fact in this issue it seems that non-Muslim rights are already breached, because al-

${ }^{33}$ Kompas, 18 April 2008 and http://news.okezone.com 20 June 2008.

${ }^{34}$ See the Impartial Team Report, "Penyeragaman and totalisasi Dunia Kehidupan sebagai Ancaman terhadap Hak Asasi Manusia”, Sebuah Studi Kebijakan di Indonesia, 2006.

${ }^{35}$ Studi Kebijakan di Indonesia, "Penyeragaman and Totalisasi Dunia Kehidupan sebagai Ancaman terhadap Hak Asasi Manusia, (Tim Imparsial), December 2006. 
though no regulation covers this, marriage across religions is forbidden by national law, Presidential Instruction 1 of 1999 concerning Compilation of Islamic Law (and more precisely paragraph 61 of this law) which among other things regulates marriage. This Presidential Instruction follows from Law 1 of 1974, which provides that a marriage is legal if it is celebrated according to the rules of each religion and faith. Marriage across religions is also forbidden by a fatwa (religious ruling) of the Indonesian Council of Ulama (MUI) through its Decision No. 5 of 1980 (No.5/Kep/ Munas II/MUI/1980). This fatwa makes any form of inter-faith marriage unlawful. The basis of the argument is that the mafsadah (community damage) would be greater than the community good. ${ }^{36}$ It is therefore not surprising that the CSRC survey by the writer and colleagues in six shariah bylaw areas showed that almost all Muslim respondents disagreed with inter-faith marriages, both between a male Muslim and a female non-Mus$\mathrm{lim}$, or vice-versa. Marriage between a female Muslim and a non-Muslim male is more undesirable. At the same time non-Muslims display a different attitude. Most of them said that inter-faith marriage was not a problem, either between one of their male followers and a female of another faith or the other way around..$^{37}$

From the above discussion, in different parts of Indonesia where non-Muslims are in the majority, such as in Manokwari, Iran Jaya, there is naturally some opposition or counter-action to shariah bylaws by putting forward proposals for Scriptural laws, although

\footnotetext{
${ }^{36}$ Harun Nasution et al.., Ensiklopedi Islam, Edition 4, p. 42.

${ }^{37}$ Sukron Kamil et al.., Syari' ah Islam and HAM, pp. 209, 197-198.
}

these proposals also come from a background of sustained Islamization. Under these proposed regulations, Muslim women would be forbidden to wear a veil in public, except in a place of worship, as it is considered to be the insignia of Islam. These proposals would also outlaw public activities on Sundays, such as bringing a boat into harbor with a large number of passengers. The reason given is that this would cause church members, such as motorcycle taxi drivers, not to attend Sunday services. They would also ban broadcasting the Muslim call to prayer by loudspeakers, because this is disruptive and is adjudged to be disrespectful to Manokwari as a town of the Bible, where the majority of the population is Christian. ${ }^{38}$

\section{The problematics of shariah bylaws, and the importance of reinterpreting traditional shariah and disseminat- ing progressive shariah}

The large number of negative impacts, including those on non-Muslims, of the shariah bylaws or other shariah-influenced regulations noted above show that the main problem of shariah bylaws or regulations in different regions is poor public participation in their conception, to the extent that they are not scrutinized by the public, although this can be understood as commonly caused by the lack of a budget. ${ }^{39}$ As a result, shariah bylaws are often of poor quality and do not (or poorly) anticipate the consequences they give rise to.

\footnotetext{
${ }^{38}$ Binsar A. Hutabarat, "Perda Agama (Injil) dalam Perspektif Kristiani”, Jurnal Perempuan 60, Edisi September 2008, Jakarta; Yayasan Jurnal Perempuan, 2008, p. 53-55

${ }^{39}$ Saifuddin Bantasyam in the Worksop "Religious Regulations and Human Rights: Promoting Human Rights Values in Young Muslim Leader circles" in Aula BKKBN Banda Aceh, 14 May 2008. This event was held by CSRC UIN Jakarta in conjunction with PKPM and KAS.
} 
Even when there is public participation, this is only of a formal nature, where a community leader is invited to a formal discussion before the bylaw is passed. Thus what really happens more resembles a directive from above, not a forum for critically discussing and examining the bylaw in an academic and satisfactory manner.

Hence the formalization of shariah by provincial bylaws can be said not to be the real, pure aspiration of the community, although in the end they join in endorsing it. As public policy this is certainly problematic, because if a bylaw is made for the people, ideally and optimally people from a variety of community sectors should be included in the process of making the bylaw so their interests can be accommodated. It is therefore understandable that time and again, once shariah bylaws are implemented they give rise to vertical conflict within a community. Provincial bylaws such as No. 9 of 2002 concerning management of professional charitable donations in East Lombok, for example, produced waves of protest from teachers who demanded that this policy be repealed. The low level of public involvement also demonstrates the weak legitimacy of the bylaws. Formalization of shariah is essentially elitist, answering the interests of the elite and tending to ignore the voice of the ordinary people. Conversely, democracy is the political system carried on the shoulders of Reform era governance, and public involvement in the democratic state system is essential.

It is understandable if, according to a Biruen (Aceh) intellectual leader, Khairuddin Nur, the emergence of formal Islamic shariah in various regions, especially in Biruen and also generally in Aceh, is a camouflage move by the lo- cal political elite designed to distract the people's attention from their economic, social welfare and other sufferings. In this way the public's energy and concern is no longer on the failure of the region's political elite to manage social, economic and political questions, or even the corruption it practices. Rather than this, the public is steered towards historical romanticism and positive feelings for Islamic shariah. ${ }^{40}$

As regulations with sacral dimensions, the problematics of provincial bylaws emerge once the bylaw has been promulgated, namely the difficulty of raising the problems presented by bylaws influenced by Islamic shariah. This suspicion was confirmed by a female activist in Aceh, who said that implementing Islamic shariah in Aceh was a threat to freedom of opinion. These activists were afraid to question the way Islamic shariah was implemented, because of concerns that their questions would countered with "anti-Islamic" accusations. ${ }^{41}$ This statement was echoed by an academic from Syiah Kuala University, Banda Aceh. The moment he was critical of the implementation of shariah bylaws on one of Aceh's radio stations, part of the Aceh community accused him of being pro-West and anti-shariah. ${ }^{42}$

A further consequence of the lack of public participation, not least by Indonesian language experts, is that in some cases the quality of the bylaw's wording is not good. In the case of the wrongful arrest of a woman in Tangerang as an alleged prostitute, which attracted much media attention, one of the legal grounds was two ambiguous parts of paragraph

\footnotetext{
${ }^{40}$ Interview with Khairuddin Nur, Lecturer in Economics, al-Islam University, 10-08-2006.

${ }^{41}$ SeeKompas newspaper, 11/03/2006.

${ }^{42}$ Saifuddin Bantasyam in the Worksop "Perda Kegamaan and HAM".
} 
4 of Tangerang Bylaw No. 8 of 2005, concerning the Prohibition of Prostitution. These parts used the words "arouse suspicion" and "apprehension". They occurred in the sentence: "Any persons who by their attitude or manner arouse suspicion such that the apprehension arises that they are prostitutes, is prohibited from being in public streets, or in other places...".

From a legal viewpoint, shariah bylaws or other regional regulations influenced by shariah conflict with:

- Indonesia's Constitution(UUD) of 1945 (as amended), which recognizes human rights. Paragraph 29 of the Constitution of 1945 states that: "(1) The foundation of the State is Belief in One God. (2) The State guarantees each citizen the freedom to follow their own religion and to worship according to their religion and their faith". Furthermore, the second section of paragraph $28 \mathrm{i}$ of the Constitution states that: "Every person will be free of discriminatory action on whatever basis and has the right to obtain protection from any action of a discriminatory nature."

- Law No. 39 of 1999 concerning Basic Human Rights such as the freedom of religion and civil rights of all people, including non-Muslims. Paragraph 22 of this law states that: "(1) Every person is free to follow their own religion and to worship according to their religion and their faith. (2) The State guarantees the independence of each person to follow their own religion and to worship according to their religion and their faith."

- The 1948 Universal Declaration of Human Rights (UDHR), in which paragraph 18 stipulates the freedom to change religion. This paragraph reads: "Every person has the right to freedom of thought, conscience and religion; this right includes the right to change religion and faith, and freedom of religious expression by observing it, practicing it, carrying out worship and complying with it, either singly or with other people, in public or in private."

- The International Covenant on Civil and Political Rights (ICCPR)of 1966, ratified by Indonesia by Law No. 12 of 2005. This makes freedom of religion and faith a non-derogable right, thus an absolute right that must be directly guaranteed under all conditions whatsoever. Violation of these rights is categorized as a serious violation of Basic Human Rights. ${ }^{43}$

\footnotetext{
43،"Statement concerning Basic Human Rights" in an the attachment to the module of Antonius Maria Indrianto et al.(ed) Perangkat Pembangunan Perdamaian: Contoh Kerja dari para aktivis Perdamaia di Indonesia[Measures for Building Peace: working examples by peace activists in Indonesia],Jakarta, Catholic Relief Service 2003; Hak Sipil and Politik Esai-Esai Pilihan [Selected Essays on Civil rights and Politics), Jakarta: Elsam, 2001, p. 29-30; UUD (Undang-Undang Dasar) 1945versi amandemen [the Constitution of Indonesia as amended] and Law No. 39/1999 concerning Human Rights, in Team ICCE UIN Jakarta, Pendidikan Kewargaan: Demokrasi, HAM, and Masyarakat Madani,[Citizenship Education: Democracy, Human Rights and Islamic Civil Society), Jakarta: ICCE UIN Jakarta, 2003; and Ismail Hasani (ed.) Berpihak and Bertindak Intoleran: Intoleransi Masyarakat and Restriksi Negara dalam Kebebasan beragama/Berkeyakinan di Indone-
} 
- Law No. 10 of 2004 concerning the Formulation of Legislation for Regulations, and Law No. 32 of 2004 concerning Provincial Government. The reason for this is that shariah bylaws or other regional religious regulations do not comply with the provisions laid down in these two laws. Among other things, they are in breach of the fundamentals of clarity of formulation (not susceptible to variant interpretations in their execution), and of openness (all levels of the community have the widest possible opportunity to contribute to their formulation); do not reflect diversity; and are contrary to the prohibition on content of a discriminatory nature which discriminates of the basis of religious background, ethnicity, race, class, gender or social status.

- Law No. 32 of 2004, in that provincial legislation cannot conflict with higher legislation (hence the Constitution of 1945 as amended, the Law on Basic Human Rights and the laws cited above).

Finally, based on Law 10/2004 and $32 / 2004$ cited above, shariah bylaws or regional religious policies conflict with or at least threaten parts of the public interest (disrupting harmony between citizens in a community, disrupting public services, and disrupting the public peace and good order).

From the shariah viewpoint (in its

sia [Taking sides and acting with intolerance, Community intolerance and state restriction of the freedom of religion/belief in Indonesia], Jakarta: Setara, 2009, p. iii. meaning as Islamic law), particularly regarding the implementation of shariah bylaws or regional religious policies influenced by shariah, or Muslim attitudes or perceptions of Muslims towards nonMuslims as discussed above, shariah bylaws have certainly in part crossed the boundaries of shariah or are contrary to Islam itself. This is because in traditional, literal shariah nonMuslims are given freedom to hold their beliefs carry out the worship their religion requires, and follow its family laws such as marriage, divorce and dress. More than this, the Koran guarantees freedom of religion to non-Muslims. QS. 18:29, QS. 2:256, 109: 1-6, and 10:99 for example show this. As an example, QS.18:29 states that; "Whoever would be faithful, let him be faithful, and whoever would be an unbeliever (who denies belief or is atheist), let him be an unbeliever". Although this verse invites the truth of revelation, its basic principle is that belief or non-belief is a matter of freedom given to humanity by God, according to each person's choice and at their risk. Based on this verse, Amien Rais was of the opinion that in Islam, what is guaranteed is not only freedom of religion, but also freedom of atheism, as long as this does not disturb the public order. ${ }^{44}$

Apart from issues of faith, worship and family (that is, in matters of economy, criminal law and politics), in traditional shariah non-Muslims are subject to Muslim law just as Muslims are. ${ }^{45}$ However it can be seen that if this is based on the practices of the Prophet Muhammad at Medina, the views of the traditional shariah experts are not exactly (or not completely) correct. Traditional shariah perspectives like this need to be reinterpreted. If not, then traditional shariah such as this, or efforts to formalize it through bylaws or other regulations, will lack the context of

\footnotetext{
${ }^{44}$ See M. Amin Rais, Cakrawala Islam, Antara Cita and Fakta, Bandung:: Mizan, 1991, p. 5357.

${ }^{45}$ Sayyid Sabiq, Fiqh as-Sunnah, Jilid III, Cairo: Dâr Al-Tsaqafah Al-Islâmiyyah, 1365 H., pp. 48-52
} 
modernity. They will be taken as nothing but the remnants of the preindustrial age, and may even diminish the standing of Islam itself.

This reinterpretation can be done using a methodology of comparing (muqâranah):

- hadiths with different, stronger hadiths, not only by sanad (transmission) but also by matan (text),

- or by interpreting hadiths with the Koran, which has greater authority,

- or by interpreting the Koran against other parts of the Koran. ${ }^{46}$

This is because the Prophet $\mathrm{Mu}-$ hammad (after this simply referred to as the Prophet) gave freedom to non-Muslims to follow criminal law as in the hadiths bilfi'li (the hadiths giving the actions of the Prophet). When the Jewish tribes of Bani Quainuka and Bani Nadhir betrayed the Prophet by plotting with his external enemies while he was pinned down on several fronts, they were sentenced to exile from Medina. This was not done autocratically by the Prophet under the laws of Islam, but rather was decided by the leaders themselves based on their own legal conventions. ${ }^{47}$

Under literal shariah, the public rights of non-Muslims (dzimmî) are understood by traditional ulama as being different from those of Muslims. Iran's

\footnotetext{
${ }^{46}$ For further discussion of this issue, see scholarly critiques of the hadiths and ushul fiqh (the basis and methodologies for implementing Islamic law].

${ }^{47}$ Badri Yatim, Sejarah Peradaban Islam, Jakarta: Rajawali Pers, 1997, p. 29 and Montgomery Watt, Pergolakan Pemikiran Politik Islam, translated by Hamid Fahmi Zarkasyi and Taufiq Ibn Syam fromIslamic Political Thought, Jakarta: Beunebi Cipta, 1987, p. 26.
}

first Constitution, which was enacted in 1907 when Iran was ruled by the Qajar Dynasty (1786-1925), states that all citizens of Iran have the same rights at law, although paragraph 58 of this Constitution restricts the rights of non-Muslims to become Government Ministers. These positions can only be given to Muslim Iranian citizens. ${ }^{48}$ However shariah perspectives or understandings such as this are not fully accurate, as they are drawn from partial understandings of the hadiths and verses which make this distinction. Examples of this are QS. 5:51 and 2:120, which suggest that non-Muslims cannot become public leaders. In fact these verses must be balanced (interpreted/compared) with verses or hadiths which treat both Muslims and non-Muslims alike, as happened in practice in the classical history of Islam. For example, QS. 60:8 allows (equal) fair dealings and treatment of non-Muslims who work cooperatively with and do not attack or make enemies of Muslims. The same applies to economic rights. Islam not only guarantees the right of non-Muslim fellow citizens (dzimmî), to seek a livelihood, but an-Nawawi's book al-Raudhah makes it clear that they can also be allowed the benefits of inheritance. Sayyid Sabiq is of the same opinion, as this was done by the Prophet's wife Shafiyyah who bequeathed her wealth to her brother, who was a Jew. Furthermore, al-Zuhri, Abû Hanîfah, Ibn Syabramah, Ibn Sirin, Zufar (a disciple of Abû Hanîfah), Ikrimah, Jabir ibn Zaid, and Yusuf Qardhawi all allow dzimmî to obtain benefits from zakat fitrah ${ }^{49}$ - the alms paid annually

\footnotetext{
${ }^{48}$ Ihsan Ali Fauzi, "Hak Asasi Manusia", in Taufik Abadullah et al., Ensiklopedi Tematik Dunia Islam, Dinamika Masa Kini, Jakarta: Ichtiar Baru van Hoeve, 2002

${ }^{49}$ An-Nawawi, al-Raudhah, Beirut: Dar al-Kutub al-Ilmiyyah, nd. Jilid IV, p.381as cited by
} 
by Muslims - although Syafi'iyah disallows this. ${ }^{50}$ The same applies to partial comprehension of the verses which suggest the exclusivity of Islam, such as QS. 3:19 and 3:85. These two verses must be balanced by interpretation or comparison with the content of verses about the pluralism of Islam, such as QS. 11:12 and QS. 2:62.

In the event that the two methods discussed above do not fully answer charges of "cultural accommodation of change", such as non-derogable Basic Human Rights, then the shariah applied must be accompanied by another method of ijtihâd, ijtihâd being the process of interpretation through close Koranic study and reasoned judgment. This is required so the formulization of shariah as a law will not come to be seen as a legislative problem, as has happened in Aceh. An example of this is the Istishlâh method (propounding the foundations of human benefit), because as suggested by Imam Maliki (93 H/712 AD-179 H/798 AD) and asy-Syathibi $(730-790 \mathrm{H})$, the ultimate rationale lying at the core of shariah is the benefit of humankind. What is meant by human benefit is shariah in the interests of safeguarding human religion/morality ( hifzh al-dîn), the right to life (hifzh al-nafs), the right to freedom of thought ( hifzh al- 'aql), rights of mar-

Anwar Ibrahim, "Wakaf dalam Syari'at Islam”, Makalah Workshop Internasional Pemberdayaan Ekonomi Ummat melalui Pengelalolaan Wakaf Produktif, Batam: Wisma Haji Batam, 7-8 January 2002, p. 16-17, Sayyid Sâbiq, Fikih al-Sunnah, Jilid I, p. 293, 263 and Yûsuf Qardhawi, Hukum Zakat, Studi Komparatif mengenai Status and Filsafat Zakat Berdasarkan Qur'an and Hadis, translated by Salman Harun et al. from Fiqh al-Zakâh, Jakarta/Bandung: Litera Antar Nusa and Mizan, 1996, printing IV, p. 684-688

${ }^{50}$ Syaikh Zainuddin Abd Al-Aziz Al-Malibari, Fath al-Mu'în bi Syarh Qurrah al- 'Ain, Semarang: Maktabah Usaha Keluarga, nd,p. 53. riage and reproduction ( hifzh al-nasl), and economic rights, particularly those

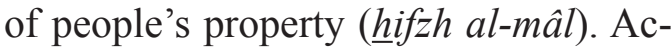
cording to Muhammad Khalid Mas'ud, an Islamic legal expert from Pakistan, the meaning of human benefit is even broader than this, and encompasses the public interest or the benefits to all humankind. ${ }^{51}$

Another method which may be used is takhshîsh, focusing especially on the application of a text, or as according to at-Thufi $(657-716 \mathrm{H})$ and Ibn Rusyd (1127-1198 AD), by the methods of Koranic exegesis (takwil) or hermeneutics. These understand the external meaning of a text as leading to the inner meaning it contains, and are based on signs within the text itself and its context. This method especially needs to be used when it is difficult to reconcile differences between the argumentation of the Koran and the hadiths on one hand, and human benefit on the other. According to these two authorities, if this occurs then by using takwil methods the human benefit or core findings can be given precedence. ${ }^{52}$ A further method that can be used is istihsân, moving from a law based on religious argument (syar'i) to another

${ }^{51} \mathrm{Abu}$ Ishaq Al-Syatibi, al-Muwâfaqât fì ushûl al-Syarî'ah, Beirut, Dâr al-Hadîts al-Kutub al-'Ilmiyyah, vol. I, part 2, pp. 7-8, 28-29 and Muhyammad Khalid Mas'ud, Filsafat Hukum Islam, Studi tentang Hidup and Pemikiran Abu Ishaq asy-Syathibi, translated from Islamic Legal Philosophy; a Study of Abu Ishaq al-Syathibi, Bandung: Pustaka, 1996, p. 191, 195

${ }^{52}$ Ahmad Munif Suratmaputra, Filsafat Hukum Islam al-Ghazali, Maslahah Mursalah and Relevansinya dengan Pembaharuan Hukum Islam, Jakarta: Pustaka Firdaus, p. 83-93, Ahmad Muhammad as-Sa' ad and Muhammad Ali al-'Umri, al-Ittijâhât al-Mu'âshirah fi Tathwîr al-Istitsmâr al-Waqfi, Kuwait: al-Amanah al'Amah li al-Auqaf, 2000, p. 30, Abu al-Walid Ibn Rusyd, Fashl al-Maqâl fimâ Baina al-Hikmah wa as-Syarî'ah min al-Ittishâl, Cairo: Dar al-Ma'arif, 1999, p. 31-32. 
religiously argued law acknowledging the desire for human benefit. This last method was used by Abu Hanifah (80 H/699-150/767 AD).

Before this, the method of Ibn Rusyd and Abu Hanifah was applied by Umar bin Khaththab (in power 13$23 \mathrm{H} / 634-644$ AD) in his ijtihâd which made human benefit the base rationale of shariah. In dividing the spoils of war he did not apply QS. 8:41, which in a literal sense required him to hand them over to the Islamic troops. Bearing in mind that the spoils of war represented land, the primary factor in production at that time, Umar in fact handed it to skilled farmers who would deliver the major part of their production to the state. The soldiers could then obtain the products of the management of this land. One of Umar's reasons was that giving the land, as the main factor in production, to the Islamic troops would result in economic injustice ${ }^{53}$, while the Koran strongly reiterates justice. ${ }^{54}$ Thus Umar carefully assessed the verses and took their real meaning as being clear, based on strong reasons (the message of other perennial verses), although this was firmly rejected by Bilal bin Rabah and his followers. Umar's ijtihâd was subsequently supported by Utsman bin Affan and Ali bin Abi Thalib, who later became the caliph.

It is therefore not surprising if the requirement to bring about human benefit as the basis of applying the law is recognized in the norms of ushukl fiqh, the

\footnotetext{
${ }^{53}$ See Paramadina,Fiqh and Reaktualisasi Hukum Islam,p. 137-143 and M. Wahyuni Nafis et al (Ed.), Kontekstualisasi Ajaran Islam, 70 Tahun Prof. Dr. Munawair Sjadzali, Jakarta: Paramadina, 1995, pp. 93-95.

${ }^{54}$ For example, QS. 4: 58 gives steps to uphold equality in law, and QS 4: 135 and QS 60: 8 advise against injustice in granting a person their rights, because justice brings us to piety (QS $5: 8)$.
}

principles and methods of applying Islamic law. More precisely, the principle applied is "managing or deciding public issues by reference to the public good" ("at-tasharruf 'alarra'iyyah manûth bil mashlahah"). This also applies to the importance of balancing the challenges of the changing times in implementing the laws in force for non-worship related issues. This can be seen in the principle: "The possibility of changing times causing changes to Islamic law cannot be denied" ("La yunkar taghayyur al-ahkâm bi taghayyur al-azmân"). ${ }^{55}$

The least that we can do is to disseminate and support progressive shariah (more consistent with the challenges of the times), but not mainstream shariah or that born of the mid-classic and modern era. An example of this is the concept of dzimmî. In traditional mainstream shariah, non-Muslims living in a Muslim country are said to be dzimmî (protected people) if they meet two conditions: (1) are willing to obey Muslim law, even though they are given freedom of religious conviction, of worship and of family law, and (2) are willing to pay jizyah, (a type of head tax) according to the literal provisions of QS. 9:29. The amount of this, according to Imam Syafi'i (150 H/767 AD-204 H/820 AD) and Imam Ahmad bin Hanbal (164/780$241 \mathrm{H} / 855 \mathrm{M}$ ), is a minimum of one dinar (gold currency), with no maximum amount determined. According to Imam Malik, the government should carefully and rationally consider (by $i j-$ tihâd) both the minimum and the maximum amounts payable, consistent with (among other things) the capacity of the non-Muslim economy.

\footnotetext{
${ }^{55}$ Mushtafa Husni as-Siba'i, Sosialisme Islam, translated by Abdai Ratomi fromIsytirakiyyah al-Islam, Bandung: Diponegoro, 1969, p. 355
} 
Shariah experts (fuqahâ) have different opinions about the function of this tax. Some see it as replacing the Muslim zakat fitrah, or annual alms tax; others see it as being for the peace given by the government, because dzimm $\hat{\imath}$ are not required to do military service; and there are others who say that it is for the welfare of the general public. ${ }^{56}$ However according to Mohammed Arkoun,seen from a human rights perspective, this concept of $d z i m m \hat{\imath}$ as protected persons is a model of uncaring tolerance (at-Tasâmuh al-Lâmubâlah(at-Tasâmuh al-Lâmubâlah). The reason is that in practice this concept comes with a hidden agenda to minimize the role of other groups and assert the excellence of Islam above all else. For him this is still not a good concept, considering the conditions of Muslims in communities of other religions. He suggests mounting an epistemological revolution by interpreting the Koran to become a shariah reference for non-Muslims, based on the modern postulates of human and social science already adopted by the West. ${ }^{57}$

Arkoun's view is in line with those of Nurcholish Madjid and the young Muslim leaders in the book Fiqh Lintas Agama(The Law Across Religions). This book explains that an analysis of QS. 9:29, which has become the foundation of the jizyah (head tax) concept in traditional shariah, must include its provenance (asbâb nuzûl), being the Tabruk War. Thus the jizyah concept only applies in a war situation, and may not be applied in normal times such as now. Moreover this book also states that $j i$ zyah is not a true Muslim tradition, but

\footnotetext{
${ }^{56}$ Sayyid Sabiq, Fiqh as-Sunnah, Jilid III, p. 4852

${ }^{57}$ Suadi Putro, Mohammaed Arkoun, Islam and Modernitas, Jakarta: Paramadina, 1998, pp 8895.
}

was adopted into Islam. ${ }^{58}$

The views of Arkoun and Nurcholish Madjid on the questions of dzimmîand jizyah (above) need to be disseminated, publicized and supported. This is because: firstly, the Medina Charter established by the Prophet himself does not only grant the freedom to embrace and practice religion (paragraph 25), but also political rights for all citizens, including non-Muslims, such as in securing the city from the attacks of external enemies (inter alia, paragraph 37).

Secondly, except during the period of Umar bin Abdul Aziz (717-720), non-Muslims were marginalized in the time of the Umayyah Dynasty (642-750 $\mathrm{AD})$, but during the "Abbasyiah Dynasty (750-1258) many non-Muslims were given public leadership positions. Many members of the Barmakiyah family, originally a Buddhist family in Balkh Persia, became generals and governors. They were also given responsibilities as tutors or trainers for kings or the young princes. This also happened with Christians and Jews. The Christian Nestorions, for example, played powerful roles in the Abbasyiah Dynasty, especially in the study of sciences, and the Bait al-Hikmah Translation Institute was headed by Hunein bin Ishaq, a Christian. At the same time the Jewish minority was involved in the areas of taxation and banking. In fact, Jews generally did better than Christians. Until it was destroyed by Mongol attacks, Bagdad had 23 synagogues..$^{59}$

\footnotetext{
${ }^{58}$ Nurcholish Madjid et al.., Fiqh Lintas Agama, Membangun Masyarakat Plural, Jakarta: Paramadina, 2004, pp. 150-153.

${ }^{59}$ Ira M. Lapidus, Sejarah Sosial Umat Islam,translated by Ghufron A. Masadi fromHistory of Islamic Society, Jakarta: Rajawali Pers, 1999 pp. 108-110, Harun Nasution, Islam Ditinjau dari Berbagai Aspeknya, Edition I, Jakarta: UI Press, 1985, pp. 67-68, and W. Mongmery
} 
Thirdly, the construct of the $d z-$ immî is a product of the place and time of its formulation, and especially of the founders of the mazhad doctrine, one of four schools of thought concerning the interpretation of Islamic law. This is because when shariah was formed, religion was organically integrated into the structure of the state. On one hand religion regulated the state, while on the other the state protected religion (al-ISlâm dîn wa daula, Islam is simultaneously a religion and a state). The form of the state at that time was a theocracy, or a nomocracy built on the laws of God. This state was established on the Islamic religion, and its citizens were categorized according to religion. The concept of the nation-state was as yet unknown, coming to birth only in the modern era. In the nation-state model and also by contemporary international law, citizenship is determined by nationality, not religion. Hence the concept of dzimmî (at least) cannot be literally applied.

Apart from the $d z i m m \hat{\imath}$ concept, one pressing issue requiring public discussion and support is that of expert views of pluralism in Islam and of apostasy (riddah, or changing religion), which differs from that of mainstream shariah. In this way the rights of non-Muslims will not be pushed aside. The concept of pluralism proposed by Cak Nur (Nurcholish Madjid) is an example of this. He holds that non-Muslims rights of religious and political freedom should be respected by acknowledging the truths and possibilities of salvation that their religions contain. It is his belief that pluralism, of which religious pluralism is a part, is not only a reality but a positive and human necessity. ${ }^{60} \mathrm{Cak}$ Nur's views Watt, Keagungan Islam,translated by Hartono Hadikusumo from The Majesty That Was Islam, Yogyakarta: Tiara Wacana, 1990, p. 94.

${ }^{60}$ Nurcholish Madjid, “Asas-Asas Pluralisme can be understood, remembering that although the Koran proclaims Islamic theology as the ideal and is critical of others such as Christianity, it also has praise for them. Furthermore it is not closed to their salvation and enlightenment. Compare, for example, QS. 5:73 with QS. 3:113-114 and QS. 2:62.

Almost all the (shariah) legal texts prescribe the death penalty for apostates, even women, who are counseled to repent but refuse. The hadith of reference is "Whosoever changes religion shall be killed." This is contrary to paragraph 18 of the Universal Declaration of Human Rights, as already discussed above. However the fact is that even in classical and mid-period shariah, death was not the one and only penalty for apostasy. For example, Imam Hanafi's reasoning equates apostates with other non-Muslims, although in his opinion this only applies to women. ${ }^{61}$ Other religious experts (ulama) who shared this opinion, but applied it to both male and female apostates, were al-Baji (died $494 \mathrm{H}$ ), an-Nakhai (died $95 \mathrm{H}$ ), Sufyan Tsauri (died $162 \mathrm{H}$ ), and Ibn Taimiyah, even though they were literalists. In their opinion all apostates from Islam should be counseled and persuaded to return to the faith, not sentenced to death. ${ }^{62}$ Moreover, modern shariah experts like Abdullahi Ahmed an-Na'im reject the death penalty for apostates, citing QS. 4:137. This verse discusses the actions of repeated acts of apostasy by a person within the Muslim commu-

and Toleransi dalam Masyarakat Madani",Makalah Seminar Masyarakat Madani dalam Perspektif Agama and Politik, Jakarta, 22 February 1999.

${ }^{61}$ Ibn ar-Rusyd, Bidâyah, op. cit., p. 343 and Syekh Zainuddin al-Malibary, op. cit., p. 127-128.

${ }^{62}$ Muhammad Hasyim Kamali, KebasanBerpendapatdalam Islam, Bandung: Mizan, 1996, p. 74-14. 
nity. Although these acts are criticized, the verse does not require a death sentence. ${ }^{63}$

The final progressive shariah issue that needs dissemination and support in its moderate concept is inter-faith marriage. Other religions forbid inter-faith marriage, at least in their mainstream perspectives. For example, in Catholicism inter-faith marriage is forbidden in principle, unless authorized by a Bishop. Protestants allow inter-faith marriage only if the non-Protestant party has no objection to the marriage being performed in the Church. In this respect civil inter-faith marriage is not recognized. Only religious marriage can be recognized.

As with other religions, within the wealth of mainstream shariah inter-faith marriage is strictly forbidden with either non-Muslim polytheists or with Christians and Jews as 'people of the book' (ahl al-kitâb), regardless of whether the male or female partner is Muslim. The reference for this is QS. 2:221, which forbids marriage with polytheist females (as equating Allah with other, pagan gods), and QS. 60:10 which makes it clear that Muslim women are not legitimate marriage partners for non-Muslim males, and vice-versa. In this regard, in the opinion of Ibn 'Umar, Christians are included with polytheists because they recognize the divinity of Jesus. In Indonesia, Decision 5/Kep/ Munas II/MUI/1980 of the Indonesian Council of Ulama makes all forms of inter-faith marriage unlawful, on the basis of the public benefit as discussed above. ${ }^{64}$ However in the full wealth of

\footnotetext{
${ }^{63}$ Abdullahi Ahmed an-Na'im, , Islam and Negara Sekuler: Menegosiasikan Masa Depan Syari'ah, Bandung-2007,Mizan, p.191.

${ }^{64}$ Harun Nasution et al., Ensiklopedi Islam, Jilid 4, p. 42 and Ahmad Sukarja, "Perkawinan
}

shariah, this injunction is not the only opinion. There are two other opinions about inter-faith marriage.

Firstly, based on QS. 5:5, a number of experts hold the opinion that a Muslim man may marry a non-Muslim woman who is 'of the book' meaning either a Jew or a Christian, however the converse does not apply and nor does it apply to a woman who is not a Jew or a Christian. As held by most of the Prophet's disciples ${ }^{65}$, in this instance a non-Muslim person of the book is not included in the polytheist category. This opinion is shared by the leaders(imam) of the four major schools of Islamic thought. However the as-Syafi' and Hambali imams impose the condition that their ancestors must have been people of the book since the time of the Prophet Muhammad. According to Sayyid Sabiq, on the authority of QS. 9:29 marriage with a woman of the book is certainly objectionable and reprehensible, but not absolutely forbidden (makrûh). At the same time the imam of the four schools of Islam forbid marriage with a woman the legitimacy of whose religion is uncertain (syubah al-kitâb), however this is allowed by Daud Zhahiri, Abu Tsur and Ibn al-Mundzir. Examples of this are women adherents of the Zoroastrian and Hindu religions. In modern times one ulama who has generally allowed marriage with non-Muslim women is Rasyid Ridha. He holds that the prohibition of marriage with polytheist women only applies to those living in Arab regions. According to him, women followers of Hindu, Buddha,

Berbeda Agama Menurut Hukum Islam", in Chuzaimah T. Yanggo and Hafiz Anshari AZ (Ed.), Problematka Hukum Islam Kontemporer, Jakarta: Pustaka Firdaus,1999, p. 10, 22-23, and Sayyid Sabiq, p.70.

${ }^{65}$ M. Quraish Shihab, Wawasan al-Qur'an, Bandung: Mizan, 1996, p. 196. 
Zoroaster, Shinto andConfuciusare permissible marriage partners. However he does not allow Muslim men whose religious convictions are not strong to marry non-Muslims, for fear that they too will become non-Muslim. ${ }^{66}$

Secondly, some modern, liberal (rational) shariah authorities, such as Musdah Mulia in Indonesia, allow marriages between both male and female Muslims and non-Muslims, without exceptions ${ }^{67}$ This third group argues from the same texts, that is QS.s 2: 221; 5: 5 , and 60: 10, but with a different interpretation. Thus Rasyid Ridha believes thatQS. 2: 221 should be understood as forbidding marriage with polytheist (pagan) Arab women only. He understands QS. 5:5 to mean the converse (mafhûm mukhâlafah), that a Muslim woman may marry a man of the book. At the same time he attributes the prohibition in QS. 60:10, banning cross-religious marriage both between a Muslim man and a non-Muslim woman and vice-versa, to the state of war prevailing at that time which made it essential to clearly identify Muslims from non-Muslims. However this state of war no longer exists and therefore the prohibition no longer applies. ${ }^{68}$ Abdullahi Ahmed an-Na'im raises another reason. He argues that the interpretation of the shariah authorities which bans marriage to partners of other religions was partly or wholly validated by a historical context which did not yet recognize basic human rights, and did not approve of religious discrimination. Today the traditional shariah view of inter-faith marriage needs to be revised in

${ }^{66}$ Mahmud Yunus, Hukum Perkawinan, pp. 4952, and see also Sayyid Sabiq, Fiqh as-Sunnah, p. 67.

${ }^{67}$ Siti Musdah Mulia, Muslimah Reformis: Perempuan Pembaru Keagamaan, Bandung: Mizan, 2004, pp. 57-59.

${ }^{68}$ Ibid, pp. 57-59, 62-63 accordance with the Universal Declaration of Human Rights. ${ }^{69}$

\section{Conclusion}

From the above discussion it can be concluded that the implementation/ formalization of shariah or shariah-influenced bylaws or other regional public policy has reached the third level, that of regulation of the aspect of ritual/worship. In this the formalization of family and economic shariah has been passed by, as is also the case with formalization of shariah at the national level. Application of shariah to the fourth level - implementing a some part of Islamic criminal law - has only occurred in Aceh, although not all the criminal law in force has the nature of shariah and this is authorized by the a law which is specific to Aceh. In general Aceh's population agrees with shariah bylaws, because people judge them to be religious instructions and a way out of the crises afflicting the country. In this, although the religious factor is strong, it appears that their agreement is prompted by social, political and economic factors. Unlike the community response, in CSO (Civil Society Organizations) circles shariah bylaws are a controversial issue.

The positive effects of implementing provincial shariah or shariah-influenced regulations or public policy are increased security, increased ZIS (charitable) donations, and heightened community religious compliance. However this third effect is less convincing.

${ }^{69}$ See Abdullahi Ahmed An Na'im, Toward an Islamic Reformation Civil Liberties, Human Rights and International Law, Indonesian edition translated as Dekonstruksi Syari'ah, Yogyakarta: LKiS, 1994 p. 173; and Abdullahi Ahmed An Na'im, "Syari'ah and Isu-Isu HAM, in Charles Kurzman (Ed.), Wacana Islam Liberal, Jakarta: Paramadina, 2001, pp. 379-388. 
More than this, seen from the angle of non-Muslim rights, shariah or shariah-influenced bylaws threaten the rights of non-Muslims by their effect as triggers and their indirect influence. For example in the case of freedom of worship, freedom to establish schools, the right to leadership, and also inter-faith marriage. Furthermore in a direct way some of these violate the rights of non-Muslims, such as mandatory wearing of the veil. In this context there is also violation of the rights of Jema'at Ahmadiyah, although shariah bylaws do not have a direct influence on this.

The main problem with shariah and shariah-influenced bylaws is diminished public scrutiny. Because of this their quality is low, their language is amenable to multiple interpretations, they reflect more the interests of the elite, and they are contrary to the 1945 Constitution (as amended), Law No. 39 of 199 concerning Basic Human Rights, the 1948 Universal Declaration of Human Rights, and the International Covenant on Civil and Political Rights. As well as this, because of their sacral character, shariah bylaws of difficult to criticize.

From the shariah perspective, regional shariah bylaws also cross the boundaries of shariah, especially in compelling the wearing of the veil and in freedom of worship. Regional shariah bylaws strongly reflect traditional shariah. Hence the shariah that is codified in bylaws must be reinterpreted by making the public benefit its guiding policy, so that contemporary challenges such as Human Rights are accommodated. At the very least the shariah which becomes bylaw should be progressive classic or modern shariah, and it needs to be disseminated for public debate, publicized and supported. As examples, and not the only ones, there are the questions of the penalty for apostasy, inter-faith marriage, pluralism in Islam, and the concept of dzimmî, which by the today's measures are still not satisfactory.

Wallâh a'lam bi as-shawâb- Only God knows the truth.

\section{Bibliography}

\section{Undang-Undang dan Perda:}

UUD (Undang-Undang Dasar) 1945versi amandemen [the Constitution of Indonesia as amended]

Law No. 39/1999 concerning Human Rights, in Team ICCE UIN Jakarta, Pendidikan Kewargaan: Demokrasi, HAM, and Masyarakat Madani,[Citizenship Education: Democracy, Human Rights and Islamic Civil Society), Jakarta: ICCE UIN Jakarta, 2003

Book:

Abd Al-Aziz Al-Malibari,Syaikh Zainuddin. Fath al-Mu'în bi Syarh Qurrah al'Ain, Semarang: Maktabah Usaha Keluarga.

Al-Syatibi, Abu Ishaq.al-Muwâfaqât fì ushûl al-Syarî'ah, Beirut, Dâr alHadîts al-Kutub al-'Ilmiyyah, vol. I, part 2 .

Amal, Taufik Adnan and Panggabean, Samsu Rizal.Politik Syari'at Islam, Dari Indonesia Hingga Nigeria, Jakarta: Pustaka Alvabet, 2004.

An Na'im, Abdullahi Ahmed.Toward an Islamic Reformation Civil Liberties, Human Rights and International Law, Indonesian edition translated as Dekonstruksi Syari'ah, Yogyakarta: LKiS, 1994.

An Na'im, Abdullahi Ahmed. "Syari'ah and 
Isu-Isu HAM, in Charles Kurzman (Ed.), Wacana Islam Liberal, Jakarta: Paramadina, 2001.

An-Na'im, Abdullahi Ahmed.Islam and Negara Sekular, Menegosiasikan Masa Depan Syariah, Bandung: Mizan, 2007.

An-Nawawi, al-Raudhah, Beirut: Dar alKutub al-Ilmiyyah, nd. Jilid IV.

as-Sa'ad, Ahmad Muhammad and al-'Umri, Muhammad Ali.al-Ittijâhât alMu'âshirah fi Tathwîr al-Istitsmâr al-Waqfi, Kuwait: al-Amanah al'Amah li al-Auqaf, 2000.

as-Siba'i,Mushtafa Husni.Sosialisme Islam, translated by Abdai Ratomi fromIsytirakiyyah al-Islam, Bandung: Diponegoro, 1969.

Bantasyam, Saifuddin. in the Worksop "Religious Regulations and Human Rights: Promoting Human Rights Values in Young Muslim Leader circles" in Aula BKKBN Banda Aceh, 14 May 2008. This event was held by CSRC UIN Jakarta in conjunction with PKPM and KAS.

Effendi,Bahtiar. Islam and Negara; Tranformasi Pemikiran and Praktek Politik Islam di Indonesia, Jakarta: Paramadina, 1998.

Fauzi, Ihsan Ali. "Hak Asasi Manusia", in Taufik Abadullah et al., Ensiklopedi Tematik Dunia Islam, Dinamika Masa Kini, Jakarta: Ichtiar Baru van Hoeve, 2002.

Hasani, Ismail (ed.) Berpihak and Bertindak Intoleran: Intoleransi Masyarakat and Restriksi Negara dalam Kebebasan beragamal Berkeyakinan di Indonesia [Taking sides and acting with intolerance, Community intolerance and state restriction of the freedom of religion/belief in Indonesia], Jakarta: Setara, 2009.
Hutabarat, Binsar A."Perda Agama (Injil) dalam Perspektif Kristiani", Jurnal Perempuan 60, Edisi September 2008, Jakarta; Yayasan Jurnal Perempuan, 2008.

Ibn Rusyd, Abu al-Walid.Fashl al-Maqâl fimâ Baina al-Hikmah wa asSyarî'ah min al-Ittishâl, Cairo: Dar al-Ma'arif, 1999.

Impartial Team Report, "Penyeragaman and totalisasi Dunia Kehidupan sebagai Ancaman terhadap Hak Asasi Manusia”, Sebuah Studi Kebijakan di Indonesia, 2006.

Indrianto, Antonius Maria.(ed) Perangkat Pembangunan Perdamaian: Contoh Kerja dari para aktivis Perdamaia di Indonesia[Measures for Building Peace: working examples by peace activists in Indonesia],Jakarta, Catholic Relief Service 2003; Hak Sipil and Politik Esai-Esai Pilihan [Selected Essays on Civil rights and Politics), Jakarta: Elsam, 2001.

Kamil, Sukron. Syari'ah Islam and HAM, Dampak Perda Syariah terhadap Kebebasan Sipil, Hak-Hak Perempuan, and Non Muslim, Jakarta, CSRC UIN Jakarta and KAS, 2007

Kamil, Sukron. "Pengaruh Regulasi Bernuansa Syari'ah terhadap Kehidupan Masyarakat Kota Tangerang: Studi terhadap Perda Pelacuran, regulasi tentang perkawinan, and agama", Laporan Hasil Riset, ["The effect of shariahnuanced regulations on public life in the city of Tangerang: A study of provincial regulations for prostitution, marriage and religion", Report of Research Results], Jakarta CSRC UIN Jakarta and Respect Program, 2008.

Kamali, Muhammad Hasyim. Kebasan Berpendapat dalam Islam, Bandung: Mizan, 1996. 
Lapidus, Ira M. Sejarah Sosial Umat Islam,translated by Ghufron A. Masadi fromHistory of Islamic Society, Jakarta: Rajawali Pers, 1999.

Madjid, Nurcholish. Fiqh Lintas Agama, Membangun Masyarakat Plural, Jakarta: Paramadina, 2004.

Mas'ud, Muhammad Khalid.Filsafat Hukum Islam, Studi tentang Hidup and Pemikiran Abu Ishaq asySyathibi, translated from Islamic Legal Philosophy; a Study of Abu Ishaq al-Syathibi, Bandung: Pustaka, 1996.

Mulia, Siti Musdah.Muslimah Reformis: Perempuan Pembaru Keagamaan, Bandung: Mizan, 2004.

Munir, Lily Zakiyah. "Simbolisasi, Politisasi and Kontrol terhadap Perempuan di Aceh"in Burhanudin (Ed.), Syariat Islam Pandangan Muslim Liberal, Jakarta: JIL, 2003.

Nafis, M. Wahyuni (Ed.), Kontekstualisasi Ajaran Islam, 70 Tahun Prof. Dr. Munawair Sjadzali, Jakarta: Paramadina, 1995.

Nashir, Haedar. Gerakan Islam Syari'at, Reproduksi Salafiah Ideologis di Indonesia, Jakarta: PSAP, 2007.

Nasution, Harun. Islam Ditinjau dari Berbagai Aspeknya, Edition I, Jakarta: UI Press, 1985.

Putro, Suadi.Mohammaed Arkoun, Islam and Modernitas, Jakarta: Paramadina, 1998.

Rais, M. Amin.Cakrawala Islam, Antara Cita and Fakta, Bandung:: Mizan, 1991.

Sabiq, Sayyid.Figh as-Sunnah, Jilid III, Cairo: Dâr Al-Tsaqafah AlIslâmiyyah, 1365 H.

Shihab, M. Quraish Wawasan al-Qur'an, Bandung: Mizan, 1996.
Suratmaputra, Ahmad Munif.Filsafat Hukum Islam al-Ghazali, Maslahah Mursalah and Relevansinya dengan Pembaharuan Hukum Islam, Jakarta: Pustaka Firdaus.

Tantowi,Ubaid. "Muslim and The Limits of Tolerance, Non-Muslim Minorities under Sharia in Indonesia,"Research report, Research Fellowship for Young Moslem Scholars, Bangkok: AMAN, 2003-2004.

Thaba, Abdul Azis.Islam and Negara dalam Politik Orba, Jakarta: Gema Insani Press, 1996,

Watt, W. Mongmery. Keagungan Islam, translated by Hartono Hadikusumo from The Majesty That Was Islam, Yogyakarta: Tiara Wacana, 1990.

Yanggo, Chuzaimah T.and AZ, Hafiz Anshari (Ed.), Problematka Hukum Islam Kontemporer, Jakarta: Pustaka Firdaus,1999.

Yatim, Badri. Sejarah Peradaban Islam, Jakarta: Rajawali Pers, 1997.

\section{Magazine:}

Tempomagazine, 14 May 2006

Gatra magazine, edition 6 May2006.

Newspaper:

Kompas newspaper, 3-1-2002

Kompas, 19-03-2002

Kompas newspaper, 11/03/2006.

Kompas newspaper, 16 August 2007.

Kompas, 18 April 2008

\section{Jurnal:}

"Fransiska Silalahi: 'Kami Kesel BangetPake Jilbab"'["We're sick and tired of wearing a jilbab"], inJurnal Perempuan 60, Edisi September 2008, Jakarta; Yayasan Jurnal Perempuan, 2008 


\section{Interview:}

Interview with Pastor Rasimin, a pastor of a church in Bireun, 9-08-2006.

Interview with Haji Tjamirudin, August 2006.

Interview with Murdani Yusuf, Chairman of Commission A, DPRD [parliament], Bireun, 10-08-2006.

Interview with Ulil Absar Abdalla and Moeslim Abdurrahman

Interview with Ali Yasa' Abubakar, Head of the Islamic Shariah Service, NAD, 16-08-2006.

Interview with Khairuddin Nur, Lecturer in Economics, al-Islam University, 10-08-2006.

\section{Internet:}

http://news.okezone.com 20 June 2008. 
